\title{
Article \\ Effects of Initial Surface Evaporation on the Performance of Fly Ash-Based Geopolymer Paste at Elevated Temperatures
}

\author{
Thathsarani Kannangara *, Maurice Guerrieri, Sam Fragomeni and Paul Joseph (D)
}

check for

updates

Citation: Kannangara, T.; Guerrieri,

M.; Fragomeni, S.; Joseph, P. Effects of Initial Surface Evaporation on the Performance of Fly Ash-Based Geopolymer Paste at Elevated Temperatures. Appl. Sci. 2022, 12, 364. https://doi.org/10.3390/ app12010364

Academic Editors: Luis Laim, Aldina Santiago and Nicola Tondini

Received: 26 November 2021 Accepted: 22 December 2021 Published: 31 December 2021

Publisher's Note: MDPI stays neutral with regard to jurisdictional claims in published maps and institutional affiliations.

Copyright: (C) 2021 by the authors. Licensee MDPI, Basel, Switzerland. This article is an open access article distributed under the terms and conditions of the Creative Commons Attribution (CC BY) license (https:// creativecommons.org/licenses/by/ $4.0 /)$.

\author{
Institute for Sustainable Industries and Liveable Cities, Victoria University, Melbourne, VIC 8001, Australia; \\ maurice.guerrieri@vu.edu.au (M.G.); sam.fragomeni@vu.edu.au (S.F.); paul.joseph@vu.edu.au (P.J.) \\ * Correspondence: a.kannangara@live.vu.edu.au
}

\begin{abstract}
Geopolymer concrete is a valuable and alternative type of concrete that is free of traditional cement. Generally, geopolymer concretes require a source material, which is rich in silicon and aluminum. Furthermore, fly ash-based geopolymer concretes have been proven to have superior fire resistance, primarily due to their ceramic properties, and are inherently environmentally-friendly given their zero-cement content. This paper presents the effects on initial evaporation on the performance of fly ash-based geopolymer pastes after exposure to elevated temperatures of $400{ }^{\circ} \mathrm{C}$ and $800{ }^{\circ} \mathrm{C}$. The fly ash (FA) samples used in the present study included: Gladstone and Gladstone/Callide. The results for sealed samples placed in the oven during curing were much more consistent than the samples that were not kept covered. In addition, Gladstone fly ash-based geopolymer samples that were sealed recorded an initial maximum compressive strength reading of ca. $75 \mathrm{MPa}$, while sealed Gladstone/Callide fly ash-based geopolymer samples, of the same mix design, only recorded an initial maximum compressive strength reading of ca. $50 \mathrm{MPa}$ (both subjected to oven curing at $60{ }^{\circ} \mathrm{C}$ for $24 \mathrm{~h}$ ). However, Gladstone/Callide fly ash-based geopolymer samples exhibited a significant strength gain, ca. $90 \mathrm{MPa}$, even after being subjected to $400{ }^{\circ} \mathrm{C}$.
\end{abstract}

Keywords: geopolymer; fly ash content; surface evaporation; residual strength

\section{Introduction}

Geopolymer (GP)-based concrete, first brought into light in the 1970s by a French scientist Joseph Davidovits, is an environmentally-benign material with a relatively lower carbon footprint compared to conventional concrete made from ordinary Portland cement (OPC) [1-4]. Referred to as a next generation concrete, and also chemically classified as a polysiliate, GP can be considered as a versatile, inorganic paste similar to zeolite materials with an amorphous microstructure [5-7]. Geopolymers are generally formed through a reaction taking place between alumino-silicate minerals and alkaline solution at ambient temperatures. During this 'geopolymerization' reaction, $-\mathrm{Si}-\mathrm{O}-\mathrm{Al}-\mathrm{O}-\mathrm{bonds}$, similar to amorphous feldspar, are formed when the source material reacts with the alkaline activator [6,8-11]. The alkaline activator, which is another important factor that determines the performance of GP-based materials, can be sodium hydroxide $(\mathrm{NaOH})$ or potassium hydroxide $(\mathrm{KOH})$, which is taken in conjunction with other compounds such as sodium silicate $\left(\mathrm{Na}_{2} \mathrm{SiO}_{3}\right)$ or potassium silicate $\left(\mathrm{K}_{2} \mathrm{SiO}_{3}\right)$, sodium sulfate $\left(\mathrm{Na}_{2} \mathrm{SO}_{4}\right)$, etc. [12,13]; however, due to the availability and cost effectiveness, $\mathrm{NaOH}$ and $\mathrm{Na}_{2} \mathrm{SiO}_{3}$ solutions are generally employed [7,14-18].

There are a number of reports in the literature [4,7,19-22] highlighting that the binder material should be one that is rich in aluminum and silicon. Other related studies [18,23-26] have indicated that components such as FA, slag, and metakaolin are often used as the source material(s) as they are rich in oxides of silica and aluminum. It has been also reported that metakaolin is the most commonly used source material due to its consistent composition; however, it is relatively expensive [27]. Finely powdered FA, on the other 
hand, has since become a more popular source material. In addition to the fact that it is a waste residue from coal-based power-plants (thus making it more sustainable), FA-based GP concretes exhibit increased residual strengths after exposure to elevated temperature conditions (even up to $800{ }^{\circ} \mathrm{C}$ ) [28-30]. It was also reported that the metakaolin-based pastes underwent a significant decrease (34\%), while FA-based GP pastes displayed a $6 \%$ increase in the residual strength after exposure to $800{ }^{\circ} \mathrm{C}$ [31]. The gel microstructure of FAbased GP concretes generally control the internal moisture content, and thus plays a major role in increasing the resistance to spalling when exposed to elevated temperatures [32,33].

A study to evaluate the strength of FA-based geopolymer pastes in comparison to OPC pastes, after being exposed to elevated temperature levels, revealed that the former was more resistant to degradation than the latter [34]. In addition, it was also established that the residual compressive strength remained somewhat constant at temperatures $800-1000{ }^{\circ} \mathrm{C}$ for GP-based concretes, while the compressive strength fell to zero at $800{ }^{\circ} \mathrm{C}$ for the OPC-based concrete [35]. In another report, the compressive strength of FA-based GP pastes, reinforced with carbon and basalt fibers at $0.5,1$, and $1.5 \%$ by weight, after being exposed to temperatures of $200,400,600$, and $800^{\circ} \mathrm{C}$ was tested [26]. The results revealed better compressive strengths, lower volumetric shrinkage, and lower mass losses from samples comprising of $1 \%$ fibers. Furthermore, specimens reinforced with carbon fibers performed better compared to specimens incorporating basalt fibers over the temperature range that was employed. Bazan et al. [36] studied the influence of melamine and steel fibers on the compressive and bending strengths of FA-based GP mortar specimens. It was found that reinforcing the specimens with either of the fibers improved both types of strengths, with steel fibers having a better ability to dissipate stress during three-point bending tests, and samples with melamine fibers were shown to increase resistance to axial compression. In addition, the use of optimal curing regimes resulted in further improvements in the mechanical properties [22,37]. Aldred and Day [20] reported that the temperature pertaining to the curing regime is critical for the development of strength in GPbased concretes, with acceptable levels of initial strength were obtained when samples were subjected to higher temperatures above room temperature. Other studies have also shown that curing test samples at higher temperatures of $60-70{ }^{\circ} \mathrm{C}$ increased the compressive strength along with lower permeability level attributes [9,38]. Experiments were also carried out to gauge the effects of temperature on the strengths of the test specimens; for instance, at ambient and $60{ }^{\circ} \mathrm{C}$ for $24 \mathrm{~h}$ [39].

Through the current study, it was identified that generally hot curing conditions were most suited, with samples producing higher strength readings compared to samples subjected to ambient-temperature curing. Unlike ordinary cement-based concretes, GP-based concretes generally require high-temperature curing to achieve the bonding between constituent molecules, and hence result in the formation of a stronger microstructures [40]. However, it was also found that curing at very high temperatures of (i.e., typically over $90^{\circ} \mathrm{C}$ ) had an adverse effect on the development of desirable physical properties. For instance, the compressive strengths of specimens cured above $90{ }^{\circ} \mathrm{C}$ were found to be noticeably reduced in comparison to specimens cured at temperatures below $90{ }^{\circ} \mathrm{C}$. This was assumed to be due to the continuous loss of moisture during curing at elevated temperatures, which also led to shrinkage cracks due to excessive drying, thus, producing weaker specimens [41].

It was reported that ambient temperature curing of GP-based concrete tends to produce low strength specimens in the initial phases [42]; however, these specimens significantly gain strength with time. Furthermore, it was noted that by increasing the curing time to at least $20 \mathrm{~h}$, the rate of the geopolymerization reaction could be enhanced, thus producing specimens with improved strengths [42]. The report also indicated that while curing GP-based materials at temperatures between $40-80{ }^{\circ} \mathrm{C}$ did achieve the optimum compressive strength readings, it was also necessary to cure specimens for longer periods to obtain enhanced mechanical properties such as compressive, tensile, and flexural strengths [16-18,43]. In addition, GP-based materials are reported to have achieved almost 
their full compressive strength during the first $24-48 \mathrm{~h}$ after casting and heat curing. This can be attributed to the achievement of the near complete polymerization process, and any further curing can only result in diminished returns [40,41,44,45].

Apart from its initial strength, GP-based concretes are also known to behave exceptionally well in high temperature/fire scenarios. For instance, when test samples (FA-based GP concrete) were heated up to $750{ }^{\circ} \mathrm{C}$, they revealed the good strength characteristics of the test specimens at elevated temperatures compared to counterparts made from conventional concrete [46]. In another study by Mane and Jadhav [47], the residual mass loss properties and residual strengths of FA-based GP concretes (with low calcium contents) and mortars were monitored after they were exposed up to $500^{\circ} \mathrm{C}$. It was shown that the test specimens displayed $84 \%$ more strength in comparison with OPC-based counter parts. It was also noticed that while the OPC-based mortars displayed only strength losses as the temperature was increased, the compressive strength of GP-based mortars increased upon reaching a temperature of $100{ }^{\circ} \mathrm{C}$, after which it was seen to be diminished.

GP-based concretes are indeed considered as a better alternative to conventional concretes in terms of developing a sustainable construction industry, with a $61 \%$ reduction in global warming potential and a $9.4 \%$ improvement in the human health category [48]. Partial- or full-replacement of cement using cementitious materials such as FA has been found to be one of the most effective methods in reducing the carbon footprint of concrete $[49,50]$. While numerous studies on the behavior, based on durability, strength, and other such mechanical properties of GP concretes at various exposure levels are available, research on the effects of the initial surface evaporation on FA-based GP pastes is very limited. In addition, specific literature precedents on a systematic comparison of the residual strengths of FA-based GP pastes (both Gladstone and Gladstone/Callide) are also severely lacking.

The novelty of the current work stems from the fact that we have endeavored to address the above knowledge gaps in the subject area. For instance, in the present study, we formulated a total of ten novel mix designs of FA-based GP pastes, with the main intention of monitoring the influence of the extent of the initial surface evaporation on the performance of these materials. Here, we also carefully chose two different experimental approaches that primarily differed in the extent of surface evaporation during the curing process. This was achieved by placing the samples in polymeric bags (i.e., sealed), or kept exposed (i.e., unsealed) for the entire duration of the curing regime. The effect of moisture retention on the performance of the cured samples were mainly evaluated through several tests for measuring the density, setting times, initial compressive strengths, residual strengths, and mass losses after exposure to elevated temperatures. Furthermore, testing was conducted on both varieties of FA (Gladstone and Gladstone/Callide) as the chemical compositions of these two types have nominal variations. Therefore, the effects of the changes in the chemical composition of different source materials on the test parameters were also evaluated. Thus, the relevant data and additional knowledge, gathered through the present study, will provide guidelines for the safe design of FA-based geopolymer pastes, especially when they are exposed to high temperatures. To our knowledge, there are no previously published systematic studies pertaining to the influence of moisture evaporation on FA-based GP paste samples that are made from different mix compositions.

\section{Materials and Methods}

This section provides the experimental details such as materials, sample preparation, curing procedures, and testing of cubical samples made from GP-based pastes. Here, parameters such a density, setting times, compressive strengths before and after exposure to elevated temperatures, and mass losses for sealed and unsealed samples of Gladstone FA-based GP mixtures were recorded. In addition, all of the above-mentioned parameters were also measured for Gladstone/Callide FA-based GP mixtures. All tests were conducted under laboratory conditions using fresh and hardened specimens, and measurements were conducted in triplicate, and the average values are quoted. Statistical information 
relating to the empirical parameters such as errors and standard deviations were also added where applicable.

\subsection{Materials}

The main constituents in the GP mixture were FA, sodium hydroxide, and sodium silicate. Furthermore, two different kinds of FA were used such as, Gladstone FA, and Gladstone/Callide FA. Gladstone FA was class F-low calcium FA, light grey in color, and with a particle size ranging from 1-8 $\mu \mathrm{m}$ whereas the other variety (Gladstone/Callide FA- class F-low calcium FA) was darker in color. Both FA materials were found to be similar in texture to Ordinary Portland Cement (OPC). Their chemical compositions are given in Table 1 . The fineness percentages, passing the $45 \mu \mathrm{m}$ sieve, were recorded to be approximately $86 \%$ and $80 \%$ for Gladstone FA and Gladstone/Callide FA, respectively. Sodium hydroxide and sodium silicate were used as components for the alkaline activator. Sodium silicate solution was type $\mathrm{D}$, having a ratio of silica to sodium oxide of 2.0. The sodium hydroxide solution had a strength of $60 \mathrm{w} / \mathrm{v} \%$ and a molarity of 8 (i.e., $\mathrm{mols} / \mathrm{dm}^{3}$ ).

Table 1. Chemical compositions of FA.

\begin{tabular}{ccc}
\hline & \multicolumn{2}{c}{ Oxide (wt. \%) } \\
\cline { 2 - 3 } Oxide & Gladstone FA & Gladstone/Callide FA \\
\hline $\mathrm{SiO}_{2}$ & 51.1 & 52.8 \\
$\mathrm{Al}_{2} \mathrm{O}_{3}$ & 25.6 & 28.8 \\
$\mathrm{Fe}_{2} \mathrm{O}_{3}$ & 12.5 & 9.99 \\
$\mathrm{CaO}$ & 4.30 & 2.70 \\
$\mathrm{~K}_{2} \mathrm{O}$ & 0.70 & 0.45 \\
$\mathrm{MgO}$ & 1.45 & 1.13 \\
$\mathrm{Na}_{2} \mathrm{O}$ & 0.77 & 0.44 \\
$\mathrm{TiO}_{2}$ & 1.32 & 1.71 \\
$\mathrm{BaO}^{\mathrm{SO}}$ & 0.09 & 0.08 \\
$\mathrm{P}_{3} \mathrm{O}_{5}$ & 0.24 & 0.17 \\
$\mathrm{MnO}$ & 0.89 & 0.49 \\
\end{tabular}

\subsection{Specification of the Mix Design}

The details of the ten novel mix designs that were employed for this study are given in Table 2.

Table 2. Details regarding the mix designs of FA-based pastes *.

\begin{tabular}{|c|c|c|c|c|}
\hline Sample ID & $\begin{array}{c}\text { Sample } \\
\text { Composition for } \\
1 \text { kg of } \\
\text { FA-(Alkaline } \\
\text { Solution/FA Ratio; } \\
\left.\mathrm{Na}_{2} \mathrm{SiO}_{3} / \mathrm{NaOH}\right)\end{array}$ & $\begin{array}{l}\text { Sodium Silicate } \\
\text { Grade D (kg) }\end{array}$ & $\begin{array}{c}8 \mathrm{M} \mathrm{NaOH} \\
(\mathrm{kg})\end{array}$ & $\begin{array}{c}\text { Total Weight } \\
\text { (kg) }\end{array}$ \\
\hline GP 01 & GP- $0.40 ; 0.50$ & 0.133 & 0.267 & 1.40 \\
\hline GP 02 & GP-0.40; 1.00 & 0.200 & 0.200 & 1.40 \\
\hline GP 03 & GP- $0.40 ; 1.75$ & 0.255 & 0.145 & 1.40 \\
\hline GP 04 & GP- $0.40 ; 2.00$ & 0.267 & 0133 & 1.40 \\
\hline GP 05 & GP- $0.40 ; 2.50$ & 0.286 & 0.114 & 1.40 \\
\hline GP 06 & GP-0.57; 0.50 & 0.190 & 0.380 & 1.57 \\
\hline GP 07 & GP-0.57; 1.00 & 0.285 & 0.285 & 1.57 \\
\hline GP 08 & GP-0.57; 1.75 & 0.363 & 0.207 & 1.57 \\
\hline GP 09 & GP-0.57; 2.00 & 0.380 & 0.190 & 1.57 \\
\hline GP 10 & GP-0.57; 2.50 & 0.407 & 0.163 & 1.57 \\
\hline
\end{tabular}




\subsection{Mixing Procedure}

Sodium hydroxide and sodium silicate were first measured and mixed using a handheld stirrer bar until a clear, transparent solution was observed (ca. $2 \mathrm{~min}$ ). This mixture was kept aside for a few minutes before stirring with the fly ash component. This method was essentially adopted from a previously published work by Hardjito and Rangan [51]. The required amount FA was measured and mixed to the liquid solution using a Breville mixer (ca. at $50 \mathrm{rpm}$ for $2 \mathrm{~min}$ ), and then for a further $3 \mathrm{~min}$ at ca. $85 \mathrm{rpm}$, after which, $25 \mathrm{~mm}^{3}$ specimens were cast.

\subsection{Curing Regime}

After casting, the cubes with dimensions of $25 \times 25 \times 25 \mathrm{~mm}^{3}$ were immediately subjected to curing. For this, a WEISS WVC Series Temperature and Climatic Test Chamber was employed. The cubes were kept at ca. $60{ }^{\circ} \mathrm{C}$ for $24 \mathrm{~h}$. Essentially, the curing was conducted using two methods. Basically, these methods were designed to test the influence of the extent of the surface evaporation of water on the mechanical properties of the samples; for example, compressive and residual strengths. Unsealed samples were placed in the oven at $60^{\circ} \mathrm{C}$ immediately after casting. Once hardened, samples were removed from the mold and placed back in the oven for a total of $24 \mathrm{~h}$. Sealed samples, on the other hand, were placed in the polymeric bag, soon after casting, and were subjected to an elevated temperature by placing them in an oven maintained at $60{ }^{\circ} \mathrm{C}$ (Figures 1 and 2). Gladstone/Callide FA specimens were only subjected to the sealed-curing procedure. It is to be noted here that none of the samples were subjected to a rest period (i.e., after casting), and all samples were immediately subjected to heat curing.

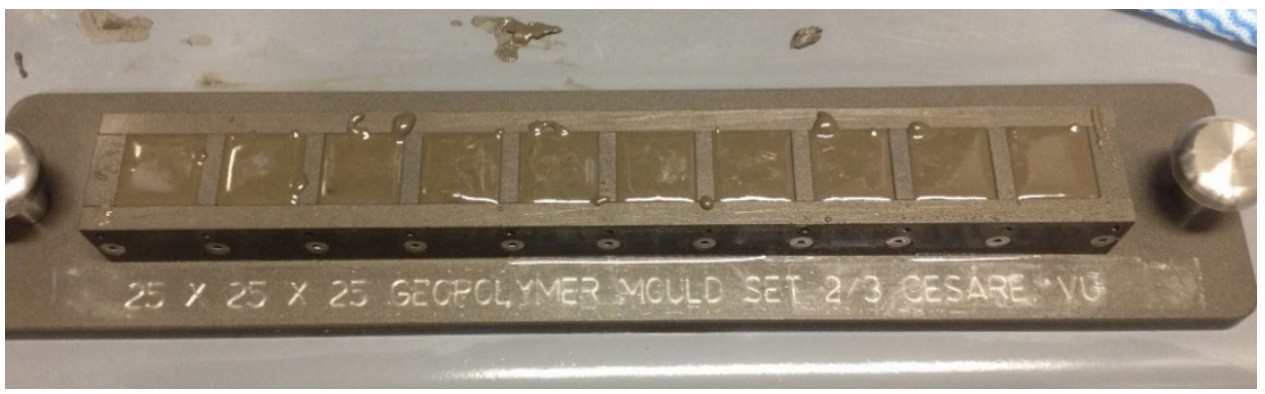

Figure 1. Gladstone FA GP casting (unsealed specimens).

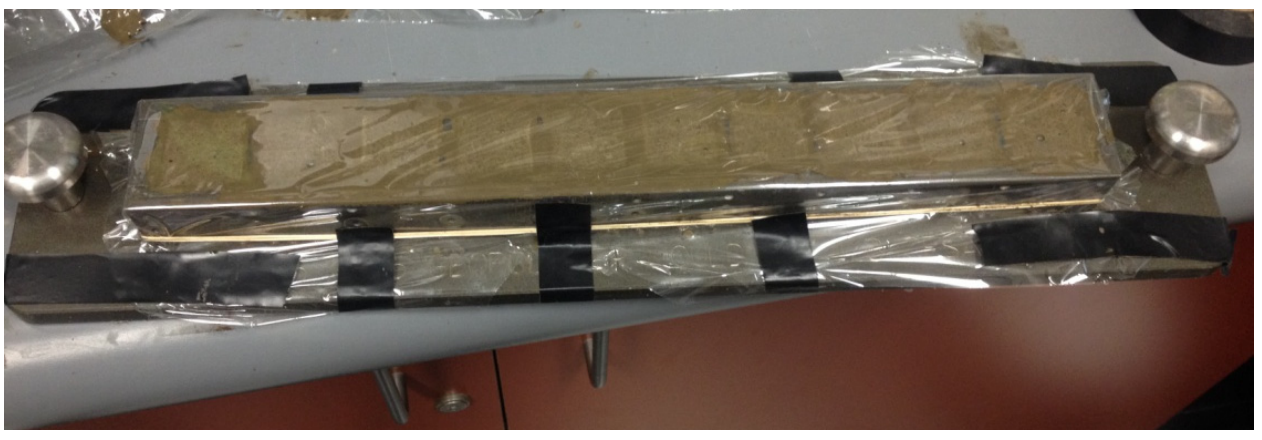

Figure 2. Gladstone FA GP casting (sealed specimens).

\subsection{Testing of Fresh and Hardened Specimens}

The density of Gladstone FA and Gladstone/Callide FA mixtures were determined, in conformance with AS 1012.5:2014 [52]. In addition, the setting times were also recorded using visual observations. For hardened specimens, the compressive and residual strengths were investigated and conducted in accordance with AS 1012.9.2014 [53]. 
The compressive strength of the test specimens was determined using a $100 \mathrm{kN}$ Instron 1195 testing machine at a loading rate of $20 \pm 2 \mathrm{MPa} / \mathrm{min}$. The Gladstone FA and Gladstone/Callide FA cubes were tested after $24 \mathrm{~h}$ of casting and curing for initial compressive strength. The samples that were tested for residual strength were subjected to heating in a muffle furnace at a steady rate of $10^{\circ} \mathrm{C} / \mathrm{min}$ to achieve the target temperatures of $400^{\circ} \mathrm{C}$ and $800{ }^{\circ} \mathrm{C}$. Upon reaching these target temperatures, samples were held at the required temperature for a period of one hour with a view to establishing the thermal equilibrium (i.e., to achieve a constant temperature throughout the samples). The samples were then permitted to cool down to room temperature (ca. $25^{\circ} \mathrm{C}$ ) before they were tested for strength. Evidently, testing the specimens for residual compressive strengths after they had been cooled down to the ambient temperature denotes the lower bound strength values compared to the stressed residual tests, where samples were tested whilst subjected to elevated temperatures, for example, as reported elsewhere [54]. The corresponding mass losses were measured using an electronic balance, where cube samples were weighed before and after exposure to elevated temperatures, and from the readings decrements, if present, were recorded.

\section{Results and Discussion}

The Gladstone FA-based GP samples exhibited higher density readings compared to Gladstone/Callide FA-based specimens. For example, the former set of samples had density values ranging from $2396 \mathrm{~kg} / \mathrm{m}^{3}$ and $2154 \mathrm{~kg} / \mathrm{m}^{3}$, and for the latter set, it was between $2059 \mathrm{~kg} / \mathrm{m}^{3}$ and $1870 \mathrm{~kg} / \mathrm{m}^{3}$. It was also found that the most-dense Gladstone FA-based GP paste was GP 10, and the most-dense Gladstone/Callide FA-based GP paste was GP 05.

When considering the setting times, it was observed that Gladstone FA-based GP pastes remained in liquid state for about $30 \mathrm{~min}$, whereas the other category of pastes set quicker than $30 \mathrm{~min}$. The initial setting times for samples such as GP 01, 02, and 03 of the Gladstone/Callide FA-based GP pastes were between 2 and $4 \mathrm{~min}$, and hence cubes of these samples could not be cast. Figure 3 shows a comparison of the morphology of Gladstone FA-based GP 01 and Gladstone/Callide FA-based GP 01 samples 5 min after casting. This could be attributed to the changes in the $\mathrm{pH}$ value of the solution with the addition of $\mathrm{NaOH}$. A higher hydroxide content has the ability to increase the alkalinity of a solution, thus, increase the $\mathrm{pH}$ value of a solution, and vice versa. In the case of GP-based materials, it was previously reported that at lower values of $\mathrm{pH}$, the GP mixture exhibited enhanced fluidity (i.e., more workable), while at relatively higher $\mathrm{pH}$ values, the mixtures exhibited increased viscosity, thus resulting in the accelerated setting [55]. This could explain why GP 01,02 , and 03 , which had a decreasing ratio of $\mathrm{Na}_{2} \mathrm{SiO}_{3}$ to $\mathrm{NaOH}$ (i.e., a higher hydroxide content), thus having an increase in $\mathrm{pH}$, set quicker than GP 04 and 05.

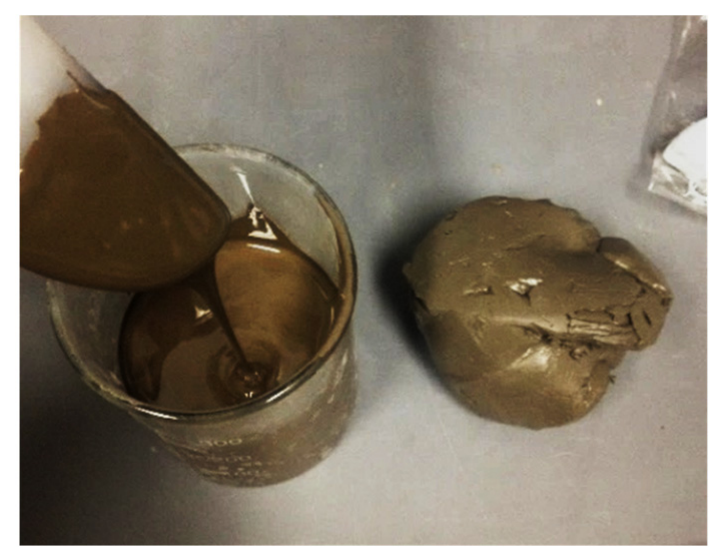

Figure 3. A picture indicating the morphological features of the mixtures: Gladstone FA GP01 (left)/Gladstone/Callide FA GP01 (right). 
It was interesting to note that the above effect did not occur in the case of Gladstone FA-based matrices. They in fact exhibited longer setting times even with the variation in the ratios of $\mathrm{Na}_{2} \mathrm{SiO}_{3}$ to $\mathrm{NaOH}$. This can be attributed to the difference in amounts of the oxides of aluminum and silicon in the formulations of the two FA materials. It was reported that aluminum can exert a significant influence on the setting times of the GP pastes [56]. For instance, it is established with lower $\mathrm{SiO}_{2}: \mathrm{Al}_{2} \mathrm{O}_{3}$ ratios produced shortened setting times, and that slight variations in the $\mathrm{Si}$ and $\mathrm{Al}$ concentrations can result in substantially different setting times for the GP mixtures. As given in Table 1, Gladstone FA had a slightly higher ratio of approximately 2.0 as opposed to 1.8 for Gladstone/Callide FA, which indicates a longer setting time in the latter case. It was also reported [57] that a higher silica content in geopolymers necessitated a higher water content. In addition to this, presence of a higher content of aluminum within the matrix can initiate quick condensation and thus accelerate the geopolymerization reaction $[58,59]$. This supports the findings from the present study, as Gladstone/Callide FA does indeed have a higher silica and aluminum content compared to Gladstone FA.

In Table 3, a comparison of the initial compressive strengths among the sealed and unsealed Gladstone FA-based GP specimens are tabulated and are graphically presented in Figure 4. It can be seen that unsealed specimens produced strengths ranging from approximately 15 to $58 \mathrm{MPa}$, while sealed specimens recorded much higher strengths ranging from approximately 23 to $74 \mathrm{MPa}$, with the highest strength recorded from GP05 for both sealed and unsealed specimens.

Table 3. Average compressive strengths $(\mathrm{MPa})$ at $24 \mathrm{~h}$ between unsealed and sealed Gladstone FA GP cubes.

\begin{tabular}{ccccc}
\hline \multirow{2}{*}{ Sample ID } & \multicolumn{2}{c}{ Unsealed Samples } & \multicolumn{2}{c}{ Sealed Samples } \\
\cline { 2 - 5 } & Strength & STDEV & Strength & STDEV \\
\hline GP 01 & 14.83 & 7.24 & 28.76 & 4.67 \\
GP 02 & 14.88 & 6.75 & 41.31 & 3.28 \\
GP 03 & 24.00 & 7.91 & 67.06 & 3.31 \\
GP 04 & 57.40 & 8.98 & 67.95 & 1.34 \\
GP 05 & 57.97 & 7.85 & 74.48 & 3.41 \\
GP 06 & 20.80 & 4.35 & 22.67 & 3.64 \\
GP 07 & 40.27 & 3.78 & 41.98 & 2.57 \\
GP 08 & 42.13 & 4.17 & 54.77 & 2.12 \\
GP 09 & 48.37 & 2.19 & 55.38 & 1.32 \\
GP 10 & 55.40 & 1.71 & 58.13 & 1.72 \\
Minimum & 14.83 & 1.71 & 22.67 & 1.32 \\
Maximum & 57.97 & 8.98 & 74.48 & 4.67 \\
Average & 37.61 & - & 51.25 & - \\
\hline
\end{tabular}

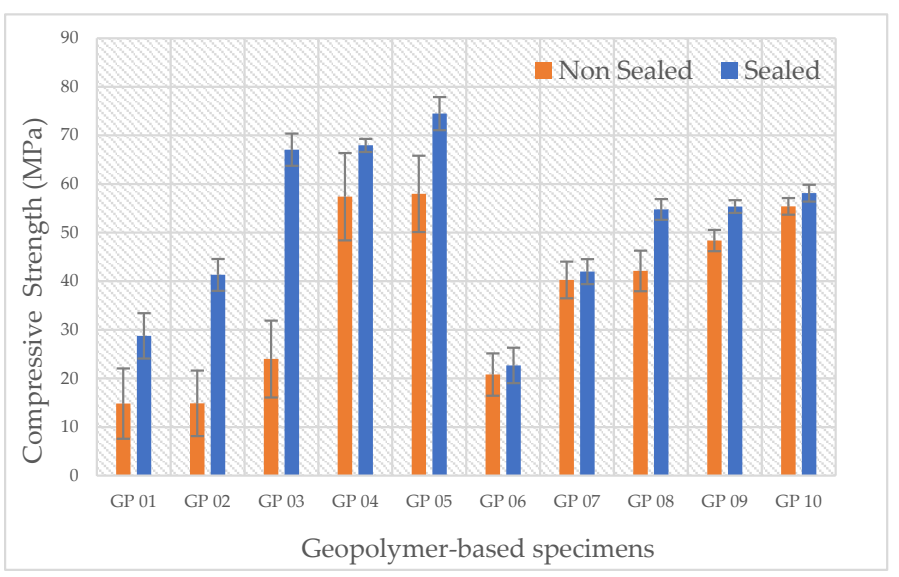

Figure 4. A plot of the initial compressive strengths among the unsealed and sealed specimens. 
An average initial strength increase of approximately $25 \%$ was recorded in the sealed specimens compared to unsealed specimens, where sealed specimens exhibited initial strength readings of up to approximately $74 \mathrm{MPa}$. This constitutes a direct evidence that initial surface evaporation plays a crucial role in the development of strength of GP pastes. The difference in strength can be attributed to the extent of the initial dehydration of the matrices during the curing process. The absence of sufficient levels of fluidity for the dissolution and gelation processes will hinder any further developments in strength during the geopolymerization reaction. Consequently, this could lead to the breakdown of the granular structure of the matrix, as reported earlier [60,61]. It has also been reported that in most cases, GP achieves 70\% of its strength during $12 \mathrm{~h}$ [62]; however, other studies [63] stated that this $70 \%$ can be reached within 3-4 h of curing. Therefore, barricading the samples from excess evaporation during this initial strength gain period will indeed produce more consistent results and relatively higher values.

The degradation of strength could also stem from the occurrence of a carbonation process. During its early setting stages, especially when the specimens are exposed to ambient conditions, $\mathrm{CO}_{2}$ can have an easy access to, and also diffuse rapidly through, the matrix. This can lead to the production of sodium bicarbonate, which in turn reduces the $\mathrm{pH}$ value, thus creating a more acidic environment, resulting in decreased formation of the alumino-silicate gel. It has been reported previously $[64,65]$ that for binders with relatively low calcium contents, higher alkaline concentrations are essential for the development of strength.

Moreover, it was noted that as the ratio of the silicate to hydroxide was increased from 0.5 to 2.5 , both sealed and unsealed specimens recorded increased compressive strengths (Table 3). In the case of unsealed specimens, the initial compressive strengths increased from approximately $14 \mathrm{MPa}$ to $58 \mathrm{MPa}$ (for GP 01 to GP 05) and from $21 \mathrm{MPa}$ to $55 \mathrm{MPa}$ (for GP06 to GP 10), and for sealed specimens, the initial compressive strengths increased from approximately $29 \mathrm{MPa}$ to $75 \mathrm{MPa}$ (for GP 01 to GP 05) and from $23 \mathrm{MPa}$ to $58 \mathrm{MPa}$ (for GP 06 to GP 10). This could be due to the inclusion of more sodium silicate as also reported previously $[18,41,66]$. Silica gel, which favors the geopolymerization reaction, also has the capacity to accelerate this process by initiating the polymerization reaction of materials, resulting in a high early strength. It was also reported that [67] the use of sodium silicate improved the geopolymerization process by accelerating the dissolution of the fly ash. Furthermore, it was established that enhancing the levels of sodium silicate increased the $\mathrm{SiO}_{2}$ to $\mathrm{Al}_{2} \mathrm{O}_{3}$ ratio, which in turn resulted in the increased number of Si-O-Si bonds, and this could lead to increased strengths [68].

However, it can be clearly noted that the initial compressive strength readings of the unsealed samples were much less consistent compared to that of the sealed samples. Unsealed GP 01, 02, and 03 specimens recorded lower strengths, and GP 04 and 05 exhibited higher strengths as the alkaline solution to the FA ratio increased from 0.4 to 0.57 . The lower readings for GP 01, 02, and 03 specimens could be attributed to insufficient levels of fluids for the dissolution of solids, and for the formation of the gel structure, brought about by early dehydration processes. In contrast, the higher strength readings of GP 04 and 05 can be due to the formation of denser microstructures, with less pores, hence resulting in higher compressive strengths. This favorably compares with previous findings [69] where it was reported that higher strengths could be achieved at an alkaline solution to FA ratio of 0.4 , compared to a ratio of $0.5-0.8$.

Severe cracking was observed in unsealed Gladstone FA-based GP upon exposure to elevated temperatures (Figures 5 and 6). On the other hand, the results obtained for sealed Gladstone FA-based GP were far more promising compared to the unsealed specimens after the exposure to heat. For these specimens, no cracking was seen in the specimens GP 01-05 and only a mild degree of cracking in GP 06-10 after exposure $400{ }^{\circ} \mathrm{C}$ and $800{ }^{\circ} \mathrm{C}$ (Figures 7 and 8). This is in line with findings from another literature precedent [61], where it was also reported that initial evaporation severely hampers the evolution in the strength 
of the specimens, thus were more likely to crack due to differential thermal gradients between the inside and outside of the samples.

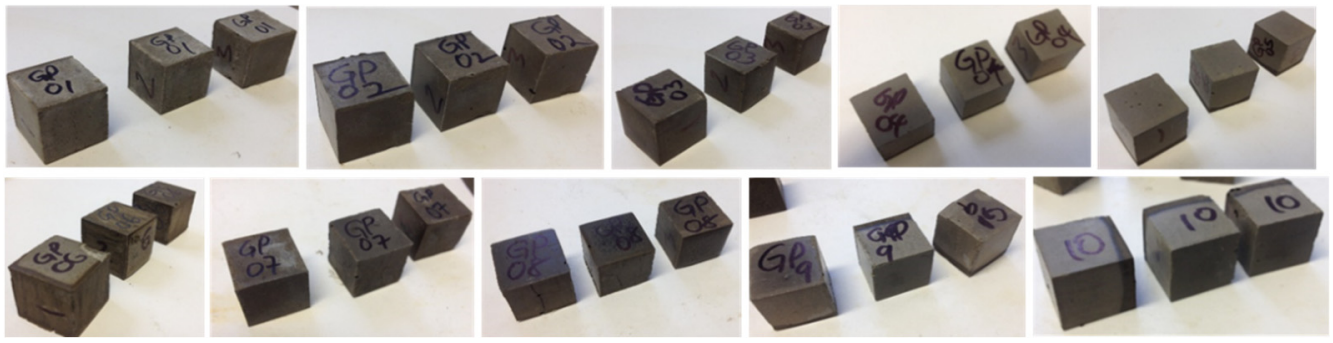

Figure 5. Pictures of unsealed Gladstone FA-based GP specimens-before exposure to an elevated temperature.

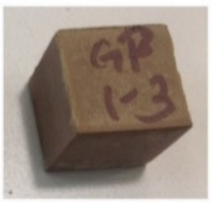

Gladstone GP0

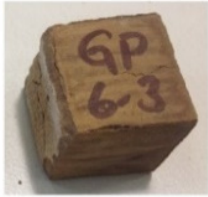

Gladstone GP06

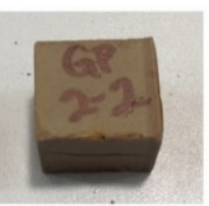

Gladstone GP02

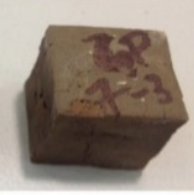

Gladstone GP07

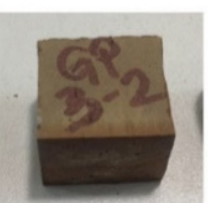

Gladstone GP03

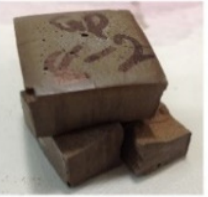

Gladstone GP08

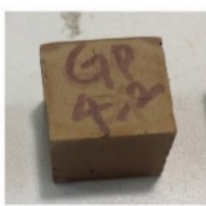

Gladstone GP04

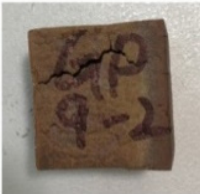

Gladstone GP09

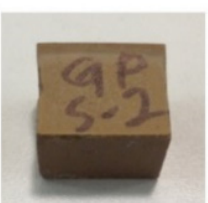

Gladstone GP05

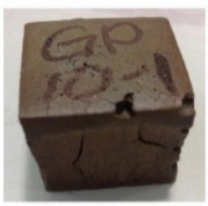

Gladstone GP10

Figure 6. Pictures of unsealed Gladstone FA-based GP specimens-after exposure to $800^{\circ} \mathrm{C}$.
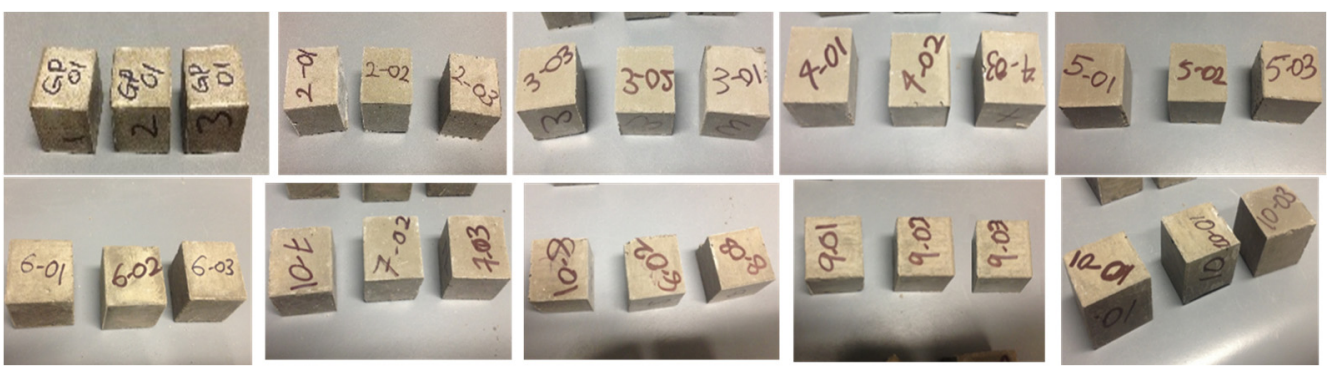

Figure 7. Pictures of sealed Gladstone FA GP specimens-before temperature exposure.

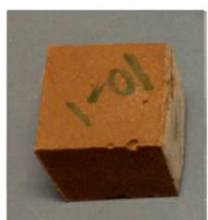

Gladstone GP01

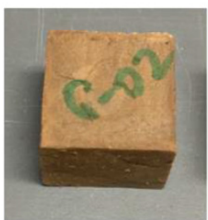

Gladstone GP06

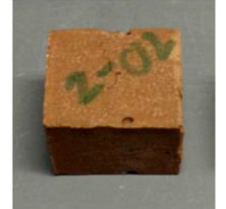

Gladstone GP02

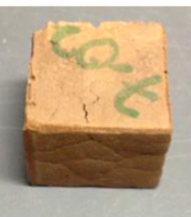

Gladstone GP07

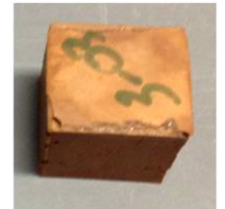

Gladstone GP03

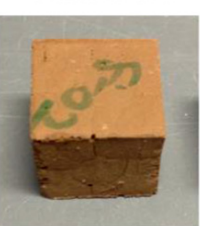

Gladstone GP08

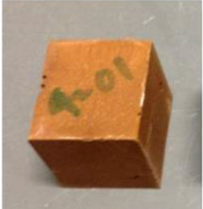

Gladstone GP04

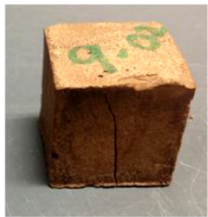

Gladstone GP09

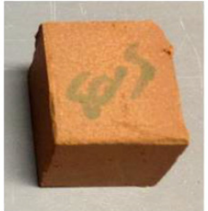

Gladstone GP05

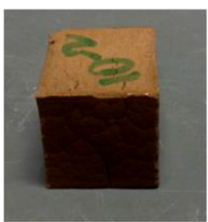

Gladstone GP10

Figure 8. Pictures of sealed Gladstone FA-based GP specimens-after exposure to $800{ }^{\circ} \mathrm{C}$. 
As previously mentioned, this could also be attributed to the lower degrees of hydration of the matrices, which could lead to the breakdown of the granular structure of the matrices, thus restricting them to evolve into a more semicrystalline form. Subsequently, this effect could cause severe cracking when exposed to differential thermal gradients, especially at elevated temperature levels. Previous studies have also reported that an initial evaporation of fluids could hinder the continuous and uniform reorganization of polycondensation processes. This could in turn hinder further development in strength and structural integrity [61]. Furthermore, earlier dehydration processes can lead to less denser structures within the material, which can result in lower compressive strengths. Such effects were also reported previously $[61,70]$, where it was also indicated that the inhibition of the ongoing geopolymerization process could result in less denser matrices, and ones with higher porous structures. These could lead to lower compressive strengths.

After exposure to $400{ }^{\circ} \mathrm{C}$, unsealed Gladstone FA-based samples recorded an average compressive strength of approximately $28 \mathrm{MPa}$, while sealed samples recorded an average compressive strength of approximately $43 \mathrm{MPa}$. After the exposure to a temperature of $800{ }^{\circ} \mathrm{C}$, unsealed Gladstone FA-based samples recorded an average compressive strength of approximately $18 \mathrm{MPa}$, while sealed samples recorded an average compressive strength of approximately $24 \mathrm{MPa}$. Tables 4 and 5 provide the data of the residual strength of unsealed and sealed samples, and Figures 9 and 10 show a graphical representation of these results.

Table 4. Values of average residual strengths (MPa): unsealed Gladstone FA-based GP cubes.

\begin{tabular}{|c|c|c|c|c|c|c|}
\hline Sample ID & $400{ }^{\circ} \mathrm{C}$ & STDEV & $800^{\circ} \mathrm{C}$ & STDEV & $\begin{array}{l}\text { Thermal } \\
\text { Cracking } \\
400{ }^{\circ} \mathrm{C}\end{array}$ & $\begin{array}{c}\text { Thermal } \\
\text { Cracking } \\
800{ }^{\circ} \mathrm{C}\end{array}$ \\
\hline GP01 & 15.14 & 6.75 & 24.27 & 4.79 & No & No \\
\hline GP02 & 26.40 & 3.30 & 22.00 & 5.25 & No & Yes \\
\hline GP03 & 26.19 & 3.48 & 22.29 & 6.04 & No & Yes \\
\hline GP04 & 31.73 & 7.06 & 23.33 & 4.27 & No & Yes \\
\hline GP05 & 52.55 & 3.12 & 25.20 & 4.06 & No & Yes \\
\hline GP06 & 13.44 & 4.65 & 15.84 & 4.86 & Yes & Yes \\
\hline GP07 & 24.48 & 5.36 & 12.11 & 3.04 & Yes & Yes \\
\hline GP08 & 26.35 & 5.85 & 12.59 & 5.04 & Yes & Yes \\
\hline GP09 & 20.81 & 5.44 & 12.37 & 3.52 & Yes & Yes \\
\hline GP10 & 30.69 & 4.00 & 13.81 & 5.20 & Yes & Yes \\
\hline Minimum & 13.44 & 3.12 & 12.11 & 3.04 & $\mathrm{~N} / \mathrm{A}$ & $\mathrm{N} / \mathrm{A}$ \\
\hline Maximum & 52.55 & 7.06 & 25.20 & 6.04 & $\mathrm{~N} / \mathrm{A}$ & $\mathrm{N} / \mathrm{A}$ \\
\hline Average & 27.81 & & 18.43 & & $\mathrm{~N} / \mathrm{A}$ & $\mathrm{N} / \mathrm{A}$ \\
\hline
\end{tabular}

Table 5. Values of average residual strengths (MPa) for sealed Gladstone FA-based GP cubes.

\begin{tabular}{ccccccc}
\hline Sample ID & $\mathbf{4 0 0}{ }^{\circ} \mathbf{C}$ & STDEV & $\mathbf{8 0 0}{ }^{\circ} \mathbf{C}$ & STDEV & $\begin{array}{c}\text { Thermal } \\
\text { Cracking } \\
\mathbf{4 0 0}{ }^{\circ} \mathbf{C}\end{array}$ & $\begin{array}{c}\text { Thermal } \\
\text { Cracking } \\
\mathbf{8 0 0}{ }^{\circ} \mathbf{C}\end{array}$ \\
\hline GP01 & 35.62 & 1.99 & 26.22 & 4.76 & No & No \\
GP02 & 47.80 & 3.22 & 35.31 & 3.35 & No & No \\
GP03 & 54.42 & 0.73 & 48.05 & 1.23 & No & No \\
GP04 & 74.14 & 1.49 & 38.29 & 0.74 & No & No \\
GP05 & 56.91 & 3.81 & 36.49 & 5.07 & No & No \\
GP06 & 17.71 & 1.47 & 10.53 & 3.61 & Yes & Yes \\
GP07 & 26.46 & 3.72 & 7.69 & 2.96 & Yes & Yes \\
GP08 & 39.99 & 3.24 & 13.37 & 2.82 & Yes & Yes \\
GP09 & 29.33 & 2.52 & 11.47 & 3.47 & Yes & Yes \\
GP10 & 39.18 & 2.83 & 9.49 & 2.16 & Yes & Yes \\
Minimum & 17.71 & 0.73 & 7.69 & 0.74 & N/A & N/A \\
Maximum & 74.14 & 3.81 & 48.05 & 5.07 & N/A & N/A \\
Average & 42.78 & & 24.39 & & N/A & N/A \\
\hline
\end{tabular}




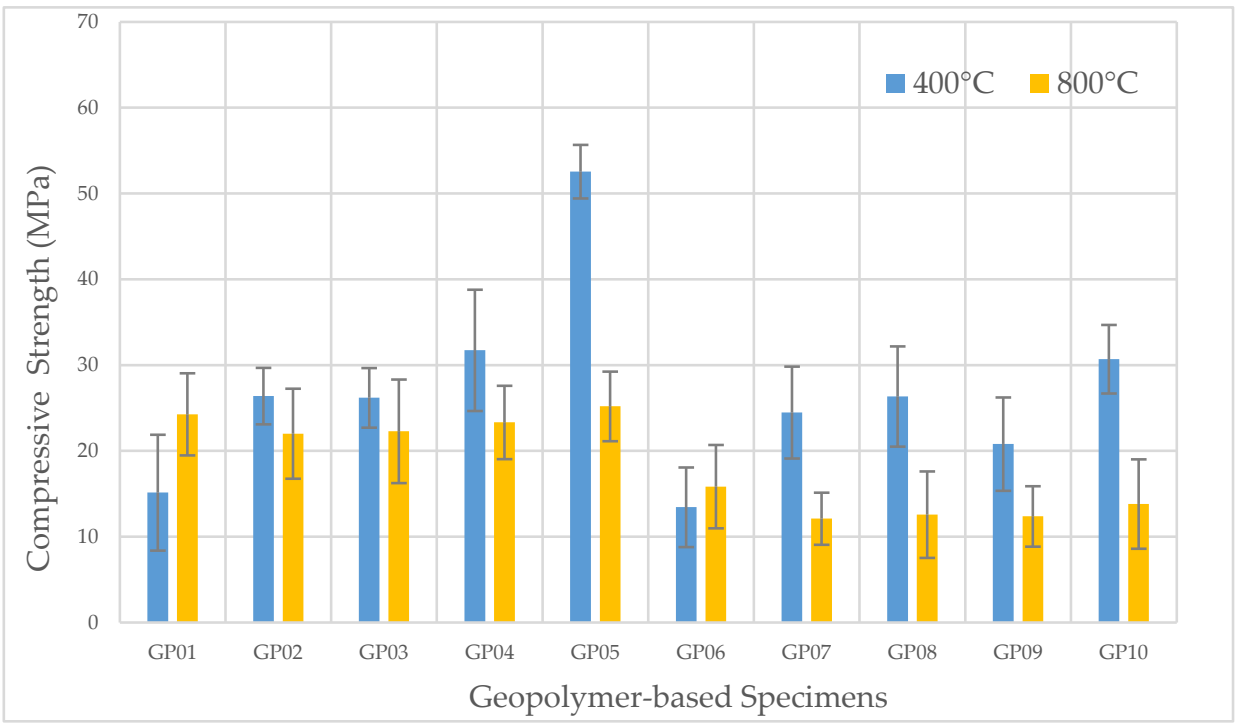

Figure 9. A plot of residual strength for unsealed Gladstone FA-based GP specimens.

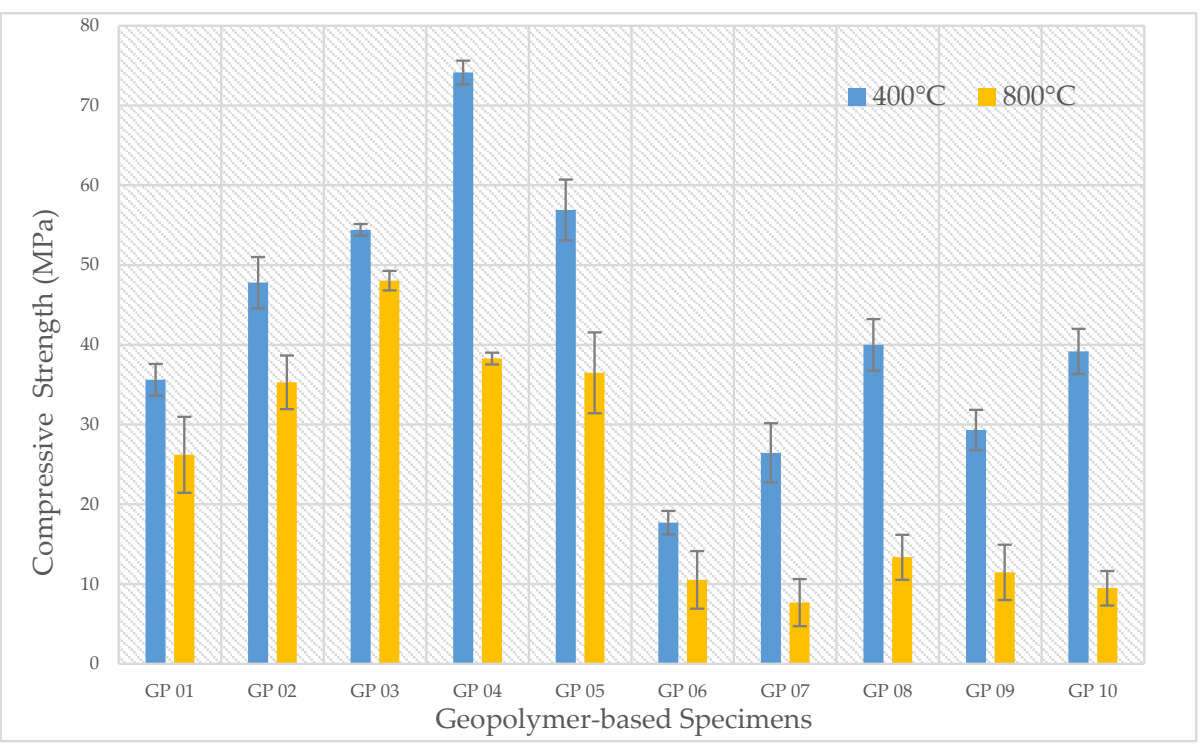

Figure 10. A plot of residual strength for sealed Gladstone FA-based GP specimens.

It was also noted that as the temperature increased to $400{ }^{\circ} \mathrm{C}$, the majority of the Gladstone FA-based GP samples having a lower ratio of alkaline solution to FA (ca. 0.4), were shown to exhibit higher residual strengths. This increase could be due to less voids within the paste matrix, which would provide thermal stability, as reported previously [70-72]. Furthermore, unsealed GP 01 and 06 specimens recorded an increase in residual strength over a range of $400{ }^{\circ} \mathrm{C}$ to $800{ }^{\circ} \mathrm{C}$, which could be attributed to the lowest $\mathrm{Na}_{2} \mathrm{SiO}_{3} / \mathrm{NaOH}$ ratio (ca. 0.5) of these two mixtures (GP 01 and 06). As sodium silicate has a higher thermal resistance, correspondingly at a higher alkali activator ratio, strength gains can be expected, even at higher temperature levels.

It is to be noted here that the majority of the Gladstone FA specimens recorded higher initial compressive strengths compared to the Gladstone/Callide FA-based GP specimens. This could be attributed to the variances in particle sizes-Gladstone FA has a fineness of $86 \%$ passing the $45 \mu \mathrm{m}$ sieve compared to $80 \%$ of the Gladstone/Callide FA. This essentially points to the fact that the former has finer particles compared to the latter. It is also reported that [73] finer particles have a higher rate of dissolution during the geopolymerization process, thus resulting in higher compressive strengths. The difference in the composition 
of the aluminosilicates has also been reported to affect the strength retention after exposure to high temperature levels [74]. A higher conversion of FA to amorphous aluminosilicate gels, and hence, a better retention of strength, has been reported at a higher $\mathrm{Si} / \mathrm{Al}$ ratio. This supports the findings of the present study, where higher strengths were recorded from Gladstone FA-based GPs, which had a Si/Al ratio of 2.0 compared to 1.8 of the Gladstone/Callide FA.

Table 6 and Figure 11 provide a tabulated and graphical comparison of the initial compressive strength between the two types of FA. In addition, GP 08 of the Gladstone/Callide FA-based specimens, which had a silicate to hydroxide ratio of 1.75 and a hydroxide solution to fly ash ratio of 0.57 , resulted in the highest initial strength reading of approximately $61 \mathrm{MPa}$. This could be due to the excessive silicate (i.e., beyond a ratio of 1.75), which can inhibit the geopolymerization process through the precipitation of the Al-Si phase [75].

Table 6. Compressive strengths (MPa) at $24 \mathrm{~h}$ among sealed Gladstone and Gladstone/Callide FA GP samples *.

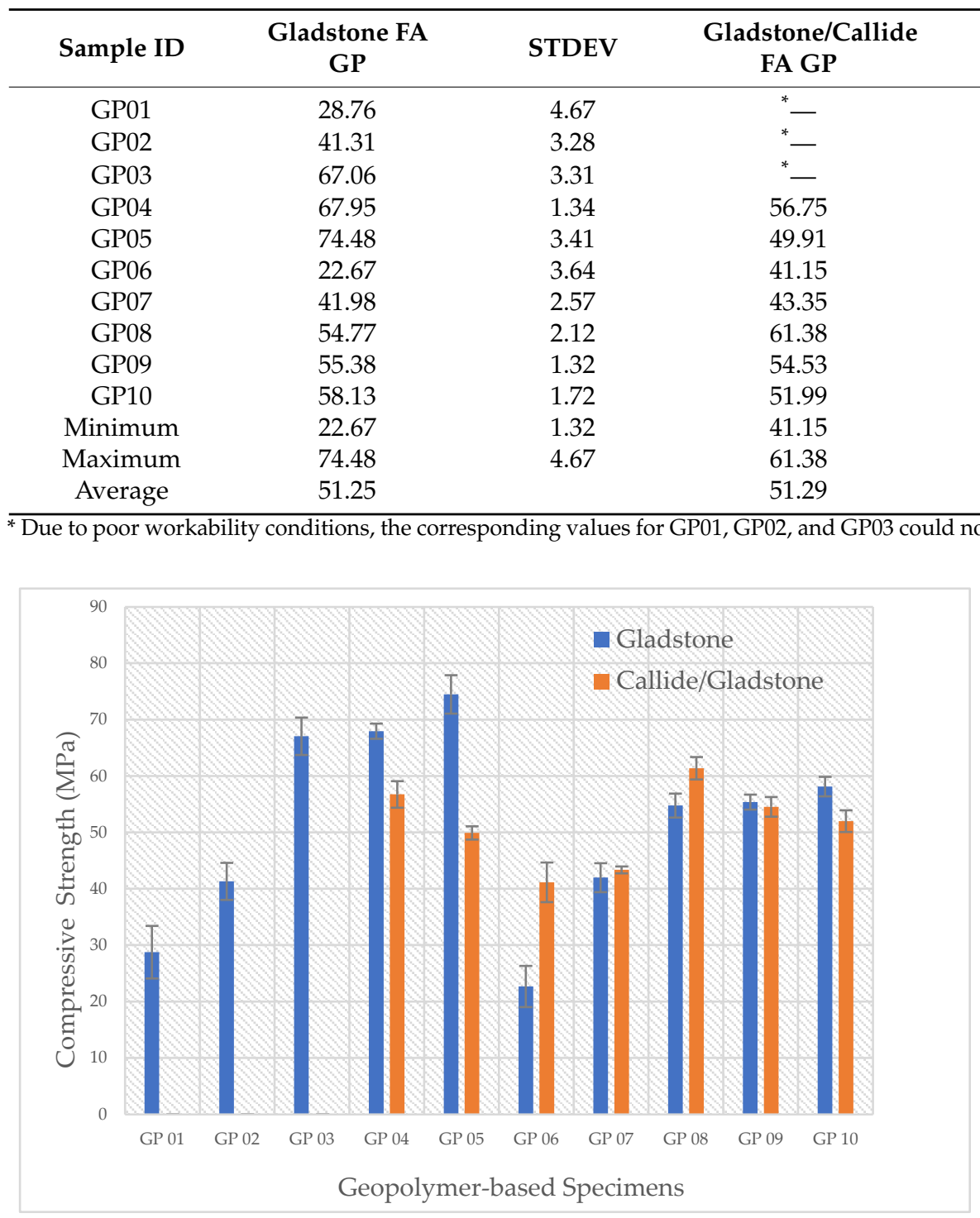

Figure 11. Initial compressive strength among the sealed Gladstone and Gladstone/Callide FA-based GP samples. 
The initial results pertaining to the strength of the samples clearly indicated that the majority of the Gladstone FA-based GP pastes performed better amongst the two classes of materials. However, while the majority of the initial compressive strengths of the Gladstone/Callide samples were low, the residual strengths were considerably high, with a striking maximum strength of approximately $90 \mathrm{MPa}$ (Table 7) compared to approximately $74 \mathrm{MPa}$ for Gladstone FA-based specimens. Similar results were previously reported $[72,76,77]$, where relatively low strength GP mixtures were observed to produce higher thermal performance and vice versa. It was also reported that this condition can be attributed to the chemical constitution, and microstructural changes occurring at higher temperatures. Samples consisting of Gladstone/Callide FA have a higher level of silicon and aluminum than Gladstone FA (Table 1). This could strongly influence the geopolymerization reactions, possibly forming the gel layer at the surface. Generally, a sintering of this gel phase is effected as temperature increases, and this in turn facilitates higher cohesive strengths, and could result in more homogeneous and denser microstructures [76,78].

Table 7. Values of average residual strengths: Gladstone/Callide FA-based GP cubes.

\begin{tabular}{ccccccc}
\hline Sample ID & $\mathbf{4 0 0}{ }^{\circ} \mathbf{C}$ & STDEV & $\mathbf{8 0 0}{ }^{\circ} \mathbf{C}$ & STDEV & $\begin{array}{c}\text { Thermal } \\
\text { Cracking } \\
\mathbf{4 0 0} \mathbf{C}\end{array}$ & $\begin{array}{c}\text { Thermal } \\
\text { Cracking } \\
\mathbf{8 0 0}{ }^{\circ} \mathbf{C}\end{array}$ \\
\hline GP 04 & 76.43 & 4.13 & 25.91 & 1.00 & No & Yes \\
GP 05 & 90.02 & 1.04 & 30.43 & 2.31 & No & Yes \\
GP 06 & 56.51 & 2.52 & 18.51 & 3.68 & No & Yes \\
GP 07 & 56.62 & 3.34 & 19.84 & 3.71 & No & Yes \\
GP 08 & 47.73 & 0.37 & 14.43 & 3.73 & No & Yes \\
GP 09 & 59.10 & 3.00 & 13.61 & 1.37 & No & Yes \\
GP 10 & 41.03 & 3.32 & 15.22 & 0.90 & No & Yes \\
Minimum & 41.03 & 0.37 & 13.61 & 0.90 & N/A & N/A \\
Maximum & 90.02 & 4.13 & 30.43 & 3.73 & N/A & N/A \\
Average & 62.05 & & 20.22 & & N/A & N/A \\
\hline
\end{tabular}

In addition, a higher degree of thermal conductivity is achieved with enhanced contents of silicon and aluminum, resulting in lower thermal gradients between the inside and outside of the specimen. Therefore, the Gladstone/Callide FA-based material has the ability to produce higher thermal energy bearing capabilities. However, the reverse effect can be expected with a lower level of Si-Al minerals (i.e., poor bonding properties and a higher thermal incompatibility within the specimen emanating from a reduced conductivity). Similar deductions have been reported elsewhere $[79,80]$. These samples with low initial strengths were observed to display higher levels of ductility and improved strength. The reverse was found to be true in the case of samples that were relatively brittle. However, when considering the overall thermal performance of the GP specimens made with either Gladstone or Gladstone/Callide FA, it can be clearly seen that they exhibited relatively good thermal stability. Similar results were reported previously [81], where the failure of GPs under thermal conditions is in fact influenced by the strength and stress-strain properties.

Generally, mass loss can be identified as an important factor when evaluating the thermal performance of concretes. The rate of mass loss upon reaching $150-200{ }^{\circ} \mathrm{C}$ was high, reported to be due to the loss of physically bound water (free water content), after which the rate somewhat stabilized, with the decomposition of $\mathrm{CaCO}_{3}$ occurring within a temperature range of $600-800{ }^{\circ} \mathrm{C}[47,79,80,82,83]$. Table 8 presents the percentage mass loss readings after exposure to $400{ }^{\circ} \mathrm{C}$ and $800{ }^{\circ} \mathrm{C}$ of the unsealed and sealed Gladstone FA-based GP samples and sealed Gladstone/Callide FA-based GP samples. 
Table 8. Average percentage of mass losses.

\begin{tabular}{ccccccc}
\hline & \multicolumn{2}{c}{$\begin{array}{c}\text { Unsealed Gladstone } \\
\text { Sample ID }\end{array}$} & \multicolumn{2}{c}{$\begin{array}{c}\text { Sealed Gladstone } \\
\text { FA-Based GP Cubes }\end{array}$} & \multicolumn{2}{c}{$\begin{array}{c}\text { Sealed } \\
\text { FAladstone/Callide }\end{array}$} \\
\cline { 2 - 7 } & $\mathbf{4 0 0}{ }^{\circ} \mathbf{C}$ & $\mathbf{8 0 0}{ }^{\circ} \mathbf{C}$ & $\mathbf{4 0 0}{ }^{\circ} \mathbf{C}$ & $\mathbf{8 0 0}{ }^{\circ} \mathbf{C}$ & $\mathbf{4 0 0}^{\circ} \mathbf{C}$ & $\mathbf{8 0 0}{ }^{\circ} \mathbf{C}$ \\
\hline GP 01 & 5.19 & 6.71 & 14.10 & 15.88 & - & - \\
GP 02 & 6.56 & 7.41 & 14.61 & 15.34 & - & - \\
GP 03 & 7.02 & 7.66 & 14.08 & 14.86 & - & - \\
GP 04 & 8.41 & 9.41 & 15.09 & 15.37 & 14.63 & 16.46 \\
GP 05 & 8.57 & 9.33 & 15.08 & 15.79 & 14.15 & 16.13 \\
GP 06 & 6.55 & 7.57 & 22.39 & 21.68 & 17.82 & 19.57 \\
GP 07 & 7.03 & 7.91 & 20.33 & 20.99 & 18.21 & 20.07 \\
GP 08 & 7.21 & 8.19 & 19.27 & 19.52 & 18.23 & 20.66 \\
GP 09 & 18.18 & 18.24 & 19.66 & 19.31 & 18.68 & 20.70 \\
GP10 & 18.13 & 18.50 & 19.75 & 20.04 & 17.27 & 17.90 \\
Minimum & 5.19 & 6.71 & 14.08 & 14.86 & 14.15 & 16.13 \\
Maximum & 18.18 & 18.50 & 22.39 & 21.68 & 18.68 & 20.70 \\
Average & 9.55 & 10.09 & 17.43 & 17.88 & 17.00 & 18.79 \\
\hline
\end{tabular}

It can be noted that the majority of the unsealed Gladstone FA-based GP specimens exhibited average mass losses (up to $10 \%$ ) when subjected to elevated temperatures $\left(400{ }^{\circ} \mathrm{C}\right.$ and $800{ }^{\circ} \mathrm{C}$ ). Sealed Gladstone FA-based GP specimens, on the other hand, recorded consistent losses, with an average mass loss of approximately $17 \%$ after being exposed to similar temperatures. The low mass loss percentage in the case of unsealed samples can be attributed to the presence of relatively lower proportions of water content in the unsealed samples. It can also be noted that large losses were recorded from the latter half of the samples (i.e., for GP 06-10). They had a higher alkaline solution to FA ratio (ca. 0.57) compared to the former half (i.e., for GP 01-05). As previously mentioned, above 1.75 (ratio of $\mathrm{Na}_{2} \mathrm{SiO}_{3}$ to $\mathrm{NaOH}$ ), the silicate in the mixture inhibited the geopolymerization reactions [75]. Therefore, the two pertinent ratios (i.e., alkaline solution to FA ratio and $\mathrm{Na}_{2} \mathrm{SiO}_{3}$ to $\mathrm{NaOH}$ ), in combination, can lead to higher mass losses. It was also reported [84] that average mass losses of FA-based GP pastes was about 19 and $20 \%$ at temperatures of $600{ }^{\circ} \mathrm{C}$ and $800{ }^{\circ} \mathrm{C}$, respectively, which are similar to the findings of the present study.

The values of mass losses for the Gladstone/Callide FA-based GP specimens were approximately $17 \%$ and $19 \%$ after being exposed to elevated temperatures of $400{ }^{\circ} \mathrm{C}$ and $800{ }^{\circ} \mathrm{C}$, respectively. The corresponding losses recorded for the Gladstone FA were somewhat similar. It can be assumed here that changes in the chemical constitution is not a key governing factor responsible for the loss of mass after heat exposure. In addition, GPs have been reported to remain chemically stable up to temperatures of about $800{ }^{\circ} \mathrm{C}$ [32].

\section{Conclusions}

This study focused on investigating the effects of initial surface evaporation on the performance of FA-based geopolymer pastes. Evaporation was controlled optionally for some test specimens by placing them in a sealed cover during the curing process. In addition, the thermal performance of two different types of Class F (low calcium) fly ash (namely Gladstone and Gladstone/Callide) was also investigated.

The main points emanating from the preset investigation can be depicted as follows:

- It can be seen that the degree of initial surface evaporation has a major effect on the final performance of the GP specimens, where sealing of the samples during the curing process, and hence limiting excess initial surface evaporation, produced more consistent results as well as much higher strength readings. 
- Unsealed specimens exhibited an approximately 25\% lesser value for the average initial strength, and approximately 35\% and 25\% lesser readings for the average residual strength readings at $400{ }^{\circ} \mathrm{C}$ and $800{ }^{\circ} \mathrm{C}$, respectively. In addition, in the case of unsealed specimens, a comparably higher degree of thermal cracking and splitting were observed compared to the sealed specimens.

- The initial strength readings also increased from approximately 15-58 MPa (GP 01-05) and 40-55 MPa (GP 06-10) for unsealed samples and 29-74 MPa (GP 01-05) and 22-58 MPa (GP 06-10) for sealed samples as the $\mathrm{Na}_{2} \mathrm{SiO}_{3} / \mathrm{NaOH}$ ratio increased from 0.5 to 2.5 , presumably due to the increased levels of sodium silicate. Furthermore, an enhanced $\mathrm{SiO}_{2}$ to $\mathrm{Al}_{2} \mathrm{O}_{3}$ ratio is likely to cause an acceleration of the geopolymerization process, and hence resulted in relatively higher early strengths for the samples.

- Majority of both Gladstone and Gladstone/Callide FA GP specimens exhibited higher initial strength readings at relatively lower alkaline solution to FA ratios. A maximum reading of approximately $75 \mathrm{MPa}$ for the Gladstone and $57 \mathrm{MPa}$ for the Gladstone/Callide FA GP specimens were recorded at 0.4 alkaline solution to FA ratio. This can be attributed to their comparatively denser microstructures, thus forming more homogenous materials with fewer number of pores.

- In the case of the Gladstone/Callide FA specimens, large increments in strength, with a striking maximum of approximately $90 \mathrm{MPa}$, was observed compared to those made from Gladstone FA after being exposed to $400{ }^{\circ} \mathrm{C}$. These variations can be attributed to a relatively higher level of silicon and aluminum, which in turn resulted in enhanced internal strength, primarily emanating from higher degrees of sintering, especially, at elevated temperatures. A higher degree of thermal conductivity can be thought to arise due to increased levels of silicon and aluminum in these specimens, which also will aid in reducing the differential thermal gradient. However, noticeable losses in strength were recorded for several of the Gladstone/Callide FA-based samples after $400{ }^{\circ} \mathrm{C}$, and this also resulted in severe cracking compared to the Gladstone FA-based samples. This may be attributed to the occurrence of an increased level of pore pressure within the samples, causing higher stresses at elevated temperatures. Hence, it can be stated that Gladstone FA-based geopolymers exhibited excellent thermal stability compared to Gladstone/Callide FA-based geopolymers.

- $\quad$ The Gladstone/Callide FA-based mixtures exhibited relatively quicker initial setting times (ca. 2-4 min) compared to the Gladstone FA-based mixtures, which remained in liquid form for over $30 \mathrm{~min}$.

Author Contributions: Conceptualization, M.G., S.F. and P.J.; Methodology, M.G. and T.K.; Validation, M.G., S.F., P.J. and T.K.; Formal analysis, T.K.; Investigation, M.G., S.F., P.J. and T.K.; Resources, M.G.; Data curation, M.G., S.F., P.J. and T.K.; Writing—original draft preparation, M.G., P.J. and T.K.; Writing-review and editing, P.J.; Supervision, M.G., S.F. and P.J.; Project administration, M.G., S.F. and P.J.; Funding acquisition, M.G. All authors have read and agreed to the published version of the manuscript.

Funding: This research received no external funding.

Institutional Review Board Statement: Not applicable.

Informed Consent Statement: Not applicable.

Data Availability Statement: Data are contained within the current article.

Acknowledgments: The authors are grateful for the technical support provided by Lyndon Macindoe and Philip Dunn, Institute for Sustainable Industries and Liveable Cities.

Conflicts of Interest: The authors declare no conflict of interest. 


\section{References}

1. Davidovits, J. 30 years of successes and failures in geopolymer applications. Market trends and potential breakthroughs. In Proceedings of the Keynote Conference on Geopolymer Conference, Melbourne, Australia, 28-29 October 2002.

2. Davidovits, J. Geopolymer, Green Chemistry and Sustainable Development Solutions: Proceedings of the World Congress Geopolymer 2005; Geopolymer Institute: Paris, France, 2005.

3. Davidovits, J. Geopolymer cement. A review. Geopolym. Inst. Tech. Pap. 2013, 21, 1-11.

4. Kannangara, A. The Behaviour of Reactive Powder Geopolymer Concrete at Elevated Temperature. Master's Thesis, Victoria University, Melbourne, Australia, 2018.

5. Abdullah, M.M.A.; Hussin, K.; Bnhussain, M.; Ismail, K.N.; Ibrahim, W.M.W. Mechanism and chemical reaction of fly ash geopolymer cement-a review. Int. J. Pure Appl. Sci. Technol. 2011, 6, 35-44.

6. Kriven, W.M.; Bell, J.L.; Gordon, M. Microstructure and microchemistry of fully-reacted geopolymers and geopolymer matrix composites. Ceram. Trans. 2003, 153, 227-250.

7. Amran, M.; Debbarma, S.; Ozbakkaloglu, T. Fly ash-based eco-friendly geopolymer concrete: A critical review of the long-term durability properties. Constr. Build. Mater. 2021, 270, 121857. [CrossRef]

8. Kupwade-Patil, K.; Allouche, E. Effect of alkali silica reaction (ASR) in geopolymer concrete. In Proceedings of the World of Coal Ash (WOCA) Conference, Denver, CO, USA, 9-12 May 2011.

9. Sindhunata, G.C.L.; Xu, H.; van Deventer, J.S. The effect of curing conditions on the properties of geopolymeric materials derived from fly ash. In International RILEM Symposium on Concrete Science and Engineering: A Tribute to Arnon Bentur; RILEM Publications SARL: Marne la Vallée, France, 2004.

10. Aleem, M.A.; Arumairaj, P. Geopolymer concrete-A review. Int. J. Eng. Sci. Emerg. Technol. 2012, 1, 118-122. [CrossRef]

11. Chen, K.; Wu, D.; Xia, L.; Cai, Q.; Zhang, Z. Geopolymer concrete durability subjected to aggressive environments-A review of influence factors and comparison with ordinary Portland cement. Constr. Build. Mater. 2021, 279, 122496. [CrossRef]

12. Amran, Y.M.; Alyousef, R.; Alabduljabbar, H.; El-Zeadani, M. Clean production and properties of geopolymer concrete; A review. J. Clean. Prod. 2020, 251, 119679. [CrossRef]

13. Zhuang, X.Y.; Chen, L.; Komarneni, S.; Zhou, C.H.; Tong, D.S.; Yang, H.M.; Yu, W.H.; Wang, H. Fly ash-based geopolymer: Clean production, properties and applications. J. Clean. Prod. 2016, 125, 253-267. [CrossRef]

14. Turner, L.K.; Collins, F.G. Carbon dioxide equivalent $\left(\mathrm{CO}_{2}-\mathrm{e}\right)$ emissions: A comparison between geopolymer and OPC cement concrete. Constr. Build. Mater. 2013, 43, 125-130. [CrossRef]

15. Davidovits, J. Geopolymers: Inorganic polymeric new materials. J. Therm. Anal. Calorim. 1991, 37, 1633-1656. [CrossRef]

16. Duxson, P.; Fernández-Jiménez, A.; Provis, J.L.; Lukey, G.C.; Palomo, A.; van Deventer, J.S. Geopolymer technology: The current state of the art. J. Mater. Sci. 2007, 42, 2917-2933. [CrossRef]

17. Palomo, A.; Grutzeck, M.; Blanco, M. Alkali-activated fly ashes: A cement for the future. Cem. Concr. Res. 1999, 29, 1323-1329. [CrossRef]

18. Hardjito, D.; Wallah, S.E.; Sumajouw, D.M.; Rangan, B.V. On the development of fly ash-based geopolymer concrete. Mater. J. 2004, 101, 467-472.

19. Bondar, D.; Lynsdale, C.J.; Milestone, N.B.; Hassani, N.; Ramezanianpour, A.A. Geopolymer cement from alkali-activated natural pozzolans: Effect of addition of minerals. In Proceedings of the 2nd International Conference on Sustainable Construction Materials and Technologies, Ancona, Italy, 28-30 June 2010.

20. Aldred, J.; Day, J. Is geopolymer concrete a suitable alternative to traditional concrete. In Proceedings of the 37th Conference on Our World in Concrete \& Structures, Singapore, 29-30 August 2012.

21. Xie, T.; Visintin, P.; Zhao, X.; Gravina, R. Mix design and mechanical properties of geopolymer and alkali activated concrete: Review of the state-of-the-art and the development of a new unified approach. Constr. Build. Mater. 2020, 256, 119380. [CrossRef]

22. Lloyd, N.; Rangan, B. Geopolymer concrete with fly ash. In Proceedings of the Second International Conference on Sustainable Construction Materials and Technologies, Ancona, Italy, 28-30 June 2010.

23. Swanepoel, J.; Strydom, C. Utilisation of fly ash in a geopolymeric material. Appl. Geochem. 2002, 17, 1143-1148. [CrossRef]

24. Rovnaník, P. Effect of curing temperature on the development of hard structure of metakaolin-based geopolymer. Constr. Build. Mater. 2010, 24, 1176-1183. [CrossRef]

25. Assi, L.N.; Carter, K.; Deaver, E.; Ziehl, P. Review of availability of source materials for geopolymer/sustainable concrete. J. Clean. Prod. 2020, 263, 121477. [CrossRef]

26. Shaikh, F.; Haque, S. Behaviour of Carbon and Basalt Fibres Reinforced Fly Ash Geopolymer at Elevated Temperatures. Int. J. Concr. Struct. Mater. 2018, 12, 1-12. [CrossRef]

27. Figiela, B.; Korniejenko, K. The possibility of using waste materials as raw materials for the production of Geopolymers. Acta Innov. 2020, 36, 48-56. [CrossRef]

28. Li, G.; $\mathrm{Wu}, \mathrm{X}$. Influence of fly ash and its mean particle size on certain engineering properties of cement composite mortars. Cem. Concr. Res. 2005, 35, 1128-1134. [CrossRef]

29. Ahmaruzzaman, M. A review on the utilization of fly ash. Prog. Energy Combust. Sci. 2010, 36, 327-363. [CrossRef]

30. Bakri, A.M.; Kamarudin, H.; Binhussain, M.; Nizar, I.K.; Rafiza, A.R.; Zarina, Y. Comparison of geopolymer fly ash and ordinary portland cement to the strength of concrete. Adv. Sci. Lett. 2013, 19, 3592-3595. [CrossRef] 
31. Kong, D.L.; Sanjayan, J.G.; Sagoe-Crentsil, K. Comparative performance of geopolymers made with metakaolin and fly ash after exposure to elevated temperatures. Cem. Concr. Res. 2007, 37, 1583-1589. [CrossRef]

32. Hassan, A.; Arif, M.; Shariq, M. Influence of microstructure of geopolymer concrete on its mechanical properties-A review. Adv. Sustain. Constr. Mater. Geotech. Eng. 2020, 35, 119-129.

33. Cao, V.D.; Pilehvar, S.; Salas-Bringas, C.; Szczotok, A.M.; Rodriguez, J.F.; Carmona, M.; Al-Manasir, N.; Kjøniksen, A.L. Microencapsulated phase change materials for enhancing the thermal performance of Portland cement concrete and geopolymer concrete for passive building applications. Energy Convers. Manag. 2017, 133, 56-66. [CrossRef]

34. Rashad, A.M.; Zeedan, S.R. The effect of activator concentration on the residual strength of alkali-activated fly ash pastes subjected to thermal load. Constr. Build. Mater. 2011, 25, 3098-3107. [CrossRef]

35. Kong, D.L.Y.; Sanjayan, J.G. Damage behavior of geopolymer composites exposed to elevated temperatures. Cem. Concr. Compos. 2008, 30, 986-991. [CrossRef]

36. Bazan, P.; Kozub, B.; Łach, M.; Korniejenko, K. Evaluation of Hybrid Melamine and Steel Fiber Reinforced Geopolymers Composites. Materials 2020, 13, 5548. [CrossRef]

37. Ryu, G.S.; Lee, Y.B.; Koh, K.T.; Chung, Y.S. The mechanical properties of fly ash-based geopolymer concrete with alkaline activators. Constr. Build. Mater. 2013, 47, 409-418. [CrossRef]

38. Shuaibu, R. Compressive Strength of Low Calcium Fly Ash Geopolymer Concrete-A Review. Int. J. Emerg. Technol. Adv. Eng. 2014, 4, 463-470.

39. Vijai, K.; Kumutha, R.; Vishnuram, B. Effect of types of curing on strength of geopolymer concrete. Int. J. Phys. Sci. 2010, 5, 1419-1423.

40. Nagral, M.R.; Ostwal, T.; Chitawadagi, M.V. Effect of curing temperature and curing hours on the properties of geo-polymer concrete. Int. J. Comput. Eng. Res. 2014, 4, 1-11.

41. Hardjito, D.; Wallah, S.E.; Sumajouw, D.M.; Rangan, B.V. Factors influencing the compressive strength of fly ash-based geopolymer concrete. Civ. Eng. Dimens. 2004, 6, 88-93.

42. Nurruddin, M.F.; Sani, H.; Mohammed, B.S.; Shaaban, I. Methods of curing geopolymer concrete: A review. Int. J. Adv. Appl. Sci. 2018, 5, 31-36. [CrossRef]

43. Singh, B.; Ishwarya, G.; Gupta, M.; Bhattacharyya, S.K. Geopolymer concrete: A review of some recent developments. Constr. Build. Mater. 2015, 85, 78-90. [CrossRef]

44. Hardjito, D.; Rangan, B.V. Development and Properties of Low-Calcium Fly Ash-Based Geopolymer Concrete; Curtin University of Technology: Bentley, Australia, 2005.

45. Ahmed, M.F.; Nuruddin, M.F.; Shafiq, N. Compressive strength and workability characteristics of low-calcium fly ash-based self-compacting geopolymer concrete. Int. J. Civ. Environ. Eng. 2011, 5, 64-70.

46. Rickard, W.D.; Gluth, G.J.; Pistol, K. In-situ thermo-mechanical testing of fly ash geopolymer concretes made with quartz and expanded clay aggregates. Cem. Concr. Res. 2016, 80, 33-43. [CrossRef]

47. Mane, S.; Jadhav, H. Investigation of geopolymer mortar and concrete under high temperature. Magnesium 2012, 1, 384-390.

48. Abbas, R.; Khereby, M.A.; Ghorab, H.Y.; Elkhoshkhany, N. Preparation of geopolymer concrete using Egyptian kaolin clay and the study of its environmental effects and economic cost. Clean Technol. Environ. Policy 2020, 26, 669-687. [CrossRef]

49. Cook, G. Climate Change and the Cement Industry; Climate Strategies: Cambridge, UK, 2022. Available online: www. climatestrategies.org (accessed on 1 November 2021).

50. Meyer, C. The greening of the concrete industry. Cem. Concr. Compos. 2009, 31, 601-605. [CrossRef]

51. Wallah, S.E.; Rangan, B.V. Low-Calcium Fly Ash-Based Geopolymer Concrete: Long-Term Properties; Curtin University of Technology: Bentley, Australia, 2006.

52. Standards Australia. Methods of Testing Concrete Method 5: Determination of Mass per Unit Volume of Freshly Mixed Concrete; Standards Australia: Sydney, Australia, 2014.

53. Standards Australia. Methods of Testing Concrete. Method 9: Compressive Strength Tests—Concrete, Mortar and Grout Specimens; Standards Australia: Sydney, Australia, 2014.

54. Phan, L. Fire Performance of High-Strength Concrete: A Report of the State of-The-Art; Building and Fire Research Laboratory, National Institute of Standards and Technology: Gaithersburg, MD, USA, 1996.

55. Roy, A.; Schilling, P.J.; Eaton, H.C. Alkali activated class C fly ash cement. J. Clean. Prod. 1997, 1, 164.

56. De Silva, P.; Sagoe-Crenstil, K.; Sirivivatnanon, V. Kinetics of geopolymerization: $\mathrm{Role}_{\mathrm{e}} \mathrm{Al}_{2} \mathrm{O}_{3}$ and $\mathrm{SiO}_{2}$. Cem. Concr. Res. 2007, 37, 512-518. [CrossRef]

57. Fletcher, R.A.; MacKenzie, K.J.D.; Nicholson, C.L.; Shimada, S. The composition range of aluminosilicate geopolymers. J. Eur. Ceram. Soc. 2005, 25, 1471-1477. [CrossRef]

58. Weng, L.; Sagoe-Crentsil, K.; Brown, T.; Song, S. Effects of aluminates on the formation of geopolymers. Mater. Sci. Eng. B 2005, 117, 163-168. [CrossRef]

59. Fernández-Jiménez, A.; Palomo, A.; Sobrados, I.; Sanz, J. The role played by the reactive alumina content in the alkaline activation of fly ashes. Microporous Mesoporous Mater. 2006, 91, 111-119. [CrossRef]

60. Heah, C.Y.; Kamarudin, H.; Al Bakri, A.M.; Binhussain, M.; Luqman, M.; Nizar, I.K.; Ruzaidi, C.M.; Liew, Y.M. Effect of curing profile on kaolin-based geopolymers. Phys. Procedia 2011, 22, 305-311. [CrossRef] 
61. Lee, S.; Van Riessen, A.; Chon, C.-M. Benefits of sealed-curing on compressive strength of fly ash-based geopolymers. Materials 2016, 9, 598. [CrossRef] [PubMed]

62. Zhang, Y.; Sun, W.; She, W.; Sun, G. Synthesis and heavy metal immobilization behaviors of fly ash based gepolymer. J. Wuhan Univ. Technol. Mater. Sci. Ed. 2009, 24, 819-825. [CrossRef]

63. Khale, D.; Chaudhary, R. Mechanism of geopolymerization and factors influencing its development: A review. J. Mater. Sci. 2007, 42, 729-746. [CrossRef]

64. Criado, M.; Palomo, A.; Fernández-Jiménez, A. Alkali activation of fly ashes. Part 1: Effect of curing conditions on the carbonation of the reaction products. Fuel 2005, 84, 2048-2054. [CrossRef]

65. Pacheco-Torgal, F.; Castro-Gomes, J.; Jalali, S. Alkali-activated binders: A review. Part 2: About materials and binders manufacture. Constr. Build. Mater. 2008, 22, 1315-1322. [CrossRef]

66. Hardjito, D.; Wallah, S.E.; Sumajouw, D.M.; Rangan, B.V. Fly ash-based geopolymer concrete. Aust. J. Struct. Eng. 2005, 6, 77-86. [CrossRef]

67. Xu, H.; Van Deventer, J. The geopolymerisation of alumino-silicate minerals. Int. J. Miner. Process. 2000, 59, 247-266. [CrossRef]

68. Al Bakri, A.M.; Kamarudin, H.; Omar, A.K.; Norazian, M.N.; Ruzaidi, C.M.; Rafiza, A.R. The effect of alkaline activator ratio on the compressive strength of fly ash-based geopolymers. Aust. J. Basic Appl. Sci. 2011, 5, 1916-1922.

69. Pavithra, P.E.; Reddy, M.S.; Dinakar, P.; Rao, B.H.; Satpathy, B.K.; Mohanty, A.N. A mix design procedure for geopolymer concrete with fly ash. J. Clean. Prod. 2016, 133, 117-125. [CrossRef]

70. Bakharev, T. Geopolymeric materials prepared using Class F fly ash and elevated temperature curing. Cem. Concr. Res. 2005, 35, 1224-1232. [CrossRef]

71. Barbosa, V.F.; MacKenzie, K.J. Thermal behaviour of inorganic geopolymers and composites derived from sodium polysialate. Mater. Res. Bull. 2003, 38, 319-331. [CrossRef]

72. Bakharev, T. Thermal behaviour of geopolymers prepared using class F fly ash and elevated temperature curing. Cem. Concr. Res. 2006, 36, 1134-1147. [CrossRef]

73. Wijaya, A.L.; Ekaputri, J.J. Factors influencing strength and setting time of fly ash based-geopolymer paste. In MATEC Web of Conferences; EDP Sciences, China Science Publishing and Media: Les Ulis, France, 2017.

74. Thokchom, S.; Mandal, K.K.; Ghosh, S. Effect of Si/Al ratio on performance of fly ash geopolymers at elevated temperature. Arab. J. Sci. Eng. 2012, 37, 977-989. [CrossRef]

75. Lee, W.; Van Deventer, J. The effects of inorganic salt contamination on the strength and durability of geopolymers. Colloids Surf. A Physicochem. Eng. Asp. 2002, 211, 115-126. [CrossRef]

76. Sarker, P.K.; Kelly, S.; Yao, Z. Effect of fire exposure on cracking, spalling and residual strength of fly ash geopolymer concrete. Mater. Des. 2014, 63, 584-592. [CrossRef]

77. Zulkifly, K.; Yong, H.C.; Abdullah, M.M.A.B.; Ming, L.Y.; Panias, D.; Sakkas, K. Review of geopolymer behaviour in thermal environment. In Iop Conference Series: Materials Science and Engineering; IOP Publishing: Bristol, UK, 2017.

78. Shaikh, F.; Vimonsatit, V. Compressive strength of fly-ash-based geopolymer concrete at elevated temperatures. Fire Mater. 2015, 39, 174-188. [CrossRef]

79. Guerrieri, M.; Sanjayan, J.G. Behavior of combined fly ash/slag-based geopolymers when exposed to high temperatures. Fire Mater. Int. J. 2010, 34, 163-175. [CrossRef]

80. Pan, Z.; Sanjayan, J.G.; Rangan, B.V. An investigation of the mechanisms for strength gain or loss of geopolymer mortar after exposure to elevated temperature. J. Mater. Sci. 2009, 44, 1873-1880. [CrossRef]

81. He, R.; Dai, N.; Wang, Z. Thermal and mechanical properties of geopolymers exposed to high temperature: A literature review. Adv. Civ. Eng. 2020, 2020, 7532703. [CrossRef]

82. Ng, K.M.; Tam, C.M.; Tam, V.W. Studying the production process and mechanical properties of reactive powder concrete: A Hong Kong study. Mag. Concr. Res. 2010, 62, 647-654. [CrossRef]

83. Zhao, X.; Liu, C.; Wang, L.; Zuo, L.; Zhu, Q.; Ma, W. Physical and mechanical properties and micro characteristics of fly ash-based geopolymers incorporating soda residue. Cem. Concr. Compos. 2019, 98, 125-136. [CrossRef]

84. Abdulkareem, O.A.; Al Bakri, A.M.; Kamarudin, H.; Nizar, I.K.; Ala'eddin, A.S. Effects of elevated temperatures on the thermal behavior and mechanical performance of fly ash geopolymer paste, mortar and lightweight concrete. Constr. Build. Mater. 2014, 50, 377-387. [CrossRef] 